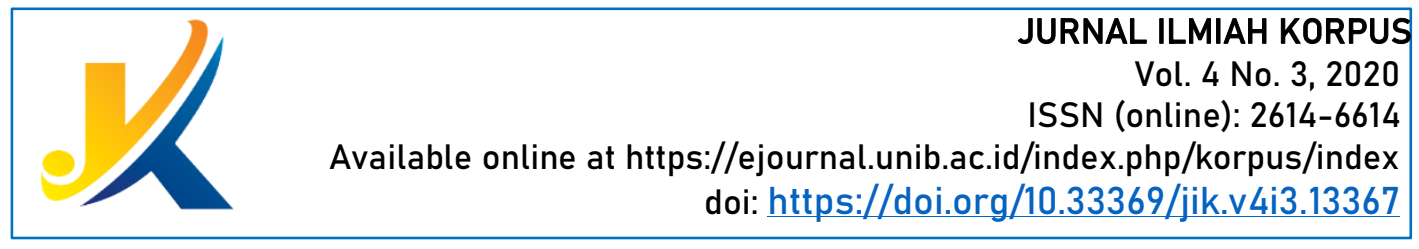

\title{
NOVEL ORANG-ORANG BIASA KARYA ANDREA HIRATA (KAJIAN SOSIOLOGI SASTRA)
}

\author{
'Septi Fatimah, ${ }^{2}$ Emi Agustina dan ${ }^{3}$ Yayah Chanafiah \\ 1,2,3Universitas Bengkulu
}

Korespondensi: septyfatimah12@gmail.com

\begin{abstract}
Abstrak
Penelitian ini bertujuan untuk: (1) mendeskripsikan gambaran sosial di lihat dari fakta cerita dalam novel Orang-Orang Biasa Ordinary People karya Andrea Hirata (2) mendeskripsikan fakta sosial yang berkaitan dengan nilai-nilai sosial dalam novel Orang-Orang Biasa Ordinary People karya Andrea Hirata. Metode yang digunakan dalam penelitian ini adala metode deskriptif kualitatif. Teknik pengumpulan data yang digunakan dalam penelitian ini adalah studi pustaka. Hasil pembahasan dalam penelitian ini yakni (1) gambaran mengenai permasalahan sosial yang terdapat di dalam novel, yakni permasalahan kemiskinan, permasalahan status sosial, dan permasalahan pendidikan yang tercermin dari fakta cerita (2) gambaran fakta sosial yang terdapat di dalam novel, yakni mengenai bentuk tindakan keadilan, kepedulian, tindakan diskriminasi sosial, dan bentuk penerapan kaidah hukum yang terdapat di dalam karya sastra.
\end{abstract}

Kata kunci: Nilai sosial, orang-orang biasa, sosiologi sastra.

\section{Abstract}

The purpose of this study was to: (1) describe the social picture in the novel Orang-Orang Biasa Ordinary People by Andrea Hirata and (2) describe the social values in the novel Orang-Orang Biasa Ordinary People by Andrea Hirata. The research in was descriptive qualitative method. Technique used in research is literature study. The results of the discussion in this study were obtained (1) decription social problems in the novel is poverty problems, social status problems, and education problems, (2) description social fact in this novel is about form of crime, concern, acts of social discrimination, and rule of law which is formed from casuality relationship in literary works.

Keywords: Social value, Orang-Orang Biasa, sociology of literature

\section{PENDAHULUAN}

Karya sastra lahir sebagai cerminan hidup bermasyarakat dan dianggap sebagai artefak budaya yang sebagian besar diterjemahkan dalam bentuk tulisan sebagai representasi pikiran dan perasaan manusia sebagai makhluk sosial. Novel merupakan bagian dari karya sastra yang lahir dari proses kreatif dan imajinatif pengarang. Sebuah novel biasanya terdapat aspek pendidikan, sosial, budaya, ekonomi, maupun politik pada zamannya dan merupakan representasi dari kehidupan sosial, serta mengandung nilainilai kemanusiaan yang terdapat di dalam masyarakat, baik nilai sosial, religius, moral, pengajaran, tanggung jawab, gotong-royong, musyawarah, saling memaafkan, kasih sayang, tolong-menolong, maupun nilai budaya. Penulis dalam penelitian ini akan membahas mengenai gambaran permasalahan-permasalahan sosial yang terdapat dalam 
novel Orang-Orang Biasa Ordinary People karya Andrea Hirata dan fakta sosial yang terdapat di dalam novel Orang-Orang Biasa Ordinary People karya Andrea Hirata.

Novel ini menggambarkan permasalahan-permasalahan sosial kaum marginal, masyarakat kecil dan kalangan menengah ke bawah. Diceritakan bahwa terdapat orangorang biasa yang mampu melakukan sesuatu yang luar biasa mereka adalah tokoh kesepuluh sekawan, yakni Debut, Salud, Tohirin, Rusip, Handai, Sobri, Honorun, Nihe, Dinah, dan Junilah dalam menjalani kehidupan yang serba sulit mereka mengalami tindakan diskriminasi sosial berupa penganiayaan dikarenakan mereka berasal dari latar belakang keluarga dengan ekonomi yang serba kekurangan dan juga tidak memiliki kemampuan akademik yang cukup baik. Selain itu terdapat pula bentuk permasalahan sosial yang digambarkan oleh tokoh Aini seorang anak miskin dan pintar yang tidak dapat melanjutkan kuliah ke fakultas kedokteraan dikarenakan terkendala oleh biaya. Hal ini dapat dilihat dari kutipan berikut.

"Novel ini kupersembabkan atas dasar kekecewaan besar dalam memperjuangkan seorang Puteri Belianti, anak miskin yang cerdas, dan kegagalan yang getir masuk. Fakultas Kedokteran, Universitas Bengkulu."

(Hirata, 2019)

Kutipan di atas menunjukkan bahwa novel ini di angkat dari kisah nyata seorang anak bernama Putri Berlianti yang pada tahun 2015 lalu diterima di di fakultas kedokteraan universitas negeri namun tidak dapat melanjutkan kuliah dikarenakan terkendala oleh biaya. Puncak permasalahan dalam novel ini ialah ketika tokoh kesepuluh sekawan terpaksa melakukan aksi merampok bank demi membantu biaya anak kuliah Aini, anak Dinah, mereka melakukan aksi perampokan bank yang mana hal tersebut merupakan tindakan tindak kriminal namun hal tersebut tetap dilakukan dan dianggap legal dikarenakan faktor keadaan. Selain menceritakan tentang perjuangan kisah kesepuluh sekawan dan Aini, di dalam novel

Novel Orang-Orang Biasa Ordinary People ini juga menceritakan tentang sikap jujur yang dimiliki oleh Inspektur Abdul Rojali seorang kepala polisi tua yang sangat menjunjung tinggi profesionalisme kerja dan memiliki tanggung jawab yang tinggi sebagai aparat penegak hukum ia dengan tegas menolak semua bentuk dan aksi penyuapan dan tindakan korupsi serta aksi kejahatan lainnya. Tokoh seperti Inspektur Abdul Rojali ini sangat dicari-cari, karena sebetulnya sekarang kita sangat kekurangan orang yang memiliki sikap jujur dan bertanggung jawab seperti dirinya.

Gambaran permasalahan dan nilai sosial yang muncul dalam novel ini sesuai dengan kenyataan. Bentuk permasalahan sosial ini dapat dipelajari lebih lanjut dalam sebuah studi ilmu yakni sosiologi sastra. Rene Wellek dan Austin Warren (1990: 110) menyatakan sosiologi sastra yaitu mengkaitkan sastra dengan situasi tertentu, atau dengan sistem politik, ekonomi dan sosial tertentu yang terbagai menjadi tiga kualisifikasi yakni:(1) Sosiologi pengarang, mencakup profesi pengarang dan intuisi sastra, masalah yang berkaitan di sini adalah dasar ekonomi produksi sastra, latar belakang status sosial pengarang, Pengarang adalah warga masyarakat, ia dapat dipelajari sebagai makhluk sosial.(2) Sosiologi karya dalam hal ini mempermasalahkan karya sastra itu sendiri dan yang berkaitan dengan masalah sosial, yang menjadi pokok penelahaannya atau apa yang tersirat dalam karya sastra dan apa yang menjadi tujuannya. Pendekatan yang umun dilakukan sosiologi ini mempelajari sastra sebagai dokumen sosial. (3) Sosiologi pembaca 
dan dampak sosial karya sastra. Pengarang dipengaruhi dan mempengaruhi masyarakat, seni tidak hanya meniru kehidupan tapi juga membentuknya.

Fakta sosial ini terjadi di dalam satu kehidupan bersama atau komunitas masyarakat yang meliputi segala bentuk hubungan yang ditandai oleh tingkat keakraban yang sangat tinggi, kedalaman emosi, komitmen moral, kohesi sosial. Komunitas dibangun atas dasar manusia dalam keutuhannya, bukan perananperanannya yang terpisah-pisah (Muhdi, 1994: 30-31).

Gambaran permasalahan sosial yang muncul dalam novel ini sesuai dan relevan dengan keadaan permasalahan yang ada, baik mengenai permasalahan kemiskikan, perbedaan status sosial, dan masalah pendidikan yang saat ini menjadi permasalahan di lingkungan masyarakat. Penelitian relevan terdahulu yang relevan dengan penelitian ini adalah penelitian yang dilakukan oleh Novita Linda Sari. 2019. Dalam skripsinya yang berjudul "Nilai-Nilai Sosial Dalam Novel Tentang Kamu Karya Tere Liye Kajian Sosiologi Sastra yang memiliki kesamaan pada analisis data yakni kesamaan nilai-nilai sosial yang ditemukan dalam sebuah karya sastra sedangkan perbedaanya adalah skripsi Linda Novita Sari mengkaji tentang nilai-nilai sosial yang terdapat di dalam novel Tentang Kamu karya Tere Liye, sementara objek penelitian penulis adalah novel Orang-Orang Biasa karya Andrea Hirata.Berdasarkan latar belakang permasalahan di atas maka penulis merumuskan permasalahan (1) Bagaimanakah gambaran sosial di lihat dari fakta cerita yang terdapat dalam Novel Orang-Orang Biasa Ordinary People karya Andrea Hirata? dan (2) Bagaimanakah fakta sosial yang terdapat dalam Novel Orang-Orang Biasa Ordinary People karya Andrea Hirata?

Tujuan dalam penelitian ini adalah (1) Mendekripsikan gambaran sosial di lihat dari fakta cerita dalam novel Orang-Orang Biasa Ordinary People karya Andrea Hirata dan (2) Mendeskripsikan fakta sosial yang dalam novel Orang-Orang Biasa Ordinary People karya Andrea Hirata.Penelitian ini bermanfaat untuk memberikan informasi mengenai permasalahan sosial yang terjadi saat ini dalam lingkungan masyarakat dan agar pembaca lebih memahami dan menerapkan sikap serta nilai sosial yang baik di lingkungan masyarakat.

\section{METODE}

Penelitian ini menggunakan metode deskriptif kualitatif. Pendekatan yang digunakan dalam penelitian ini adalah pendekatan sosiologi sastra perspektif karya Renne Wellek dan Austin Warren. Langkah-langkah dalam pendekatan sosiologi sastra ini, antara lain: (1) Menganalisis gambaran permasalahan sosial dan nilai sosial yang terdapat di dalam novel melalui pendekatan sosiologi sastra pada aspek karya (2) Menafsirkan nilai sosial yang muncul dari gambaran permasalahan sosial yang terdapat di dalam novel. Data dalam penelitian ini berupa kutipan-kutipan kalimat maupun paragraf yang terdapat di dalam novel Orang-Orang Biasa Ordinary People karya Andrea Hirata yang menunjukkan gambaran permasalahan sosial dan fakta sosial yang terdapat di dalam novel. Sumber data yang digunakan dalam penelitian ini adalah novel Orang-Orang Biasa Ordinary People karya Andrea Hirata terbitan Bentang Pustaka, Yogyakarta cetakan pertama Februari 2019 dan memiliki tebal 262 halaman.

Teknik pengumpulan data yang digunakan dalam penelitian ini adalah teknik studi pustaka yang menggunakan sumber-sumber tertulis untuk memperoleh data. Data diperoleh dalam bentuk tulisan, maka harus dibaca, dipelajari, hal-hal yang penting dicatat 
kemudian disimpulkan dan mempelajari sumber tulisan yang dapat dijadikan sebagai landasan teori dan acuan dalam hubungan dengan objek yang akan diteliti. Teknik analisis data yang digunakan dalam penelitian ini meliputi: membaca, membuat sinopsis, menandai dan mencatat permasalahan, mendeskripsikan masalah, menafsirkan masalah, menganalisis kembali maslaah, dan membuat kesimpulan akhir dari penelitian yang telah dilakukan.

\section{HASIL DAN PEMBAHASAN}

Peristiwa di dalam novel Orang-Orang Biasa Ordinary People karya Andrea Hirata telah ditemukan oleh penulis permasalahan sosial yang di lihat drai fakta cerita dan fakta sosial yang berkaitan dengan nilai sosial yang terdapat di dalam novel yakni sebagai berikut:

1. Gambaran permasalahan sosial

Gambaran permasalahan sosial dalam novel Orang-Orang Biasa Ordinary People karya Andrea Hirata ini terbagi menjadi tiga permasalahan, antara lain:

(1) Permasalahan kemiskinan

permasalahan kemiskinan ini ditunjukkan oleh tokoh kesepuluh sekawan mereka adalah orang-orang kalangan bawah yang selalu mengalami diskriminasi sosial. Kemiskinan dan keterbelakangan akademik sudah menjadi makanan sehari-hari, bagi mereka hidup hanya menjalani nasib, dan tidak punya tujuan maupun cita-cita. Kesepuluh sekawan tersebut hanyalah orang-orang biasa yang hanya mampu meyelesaikan pendidikan sampai bangku SMA, itu pun hanya beberapa yang benar-benar menamatkan masa SMA, sisanya hanya berhenti sebelum tamat dikarenakan keadaan ekonomi dan kemampuan akademik yang tidak memadai. Hal ini dapat dilihat dari kutipan berikut.

"Kekompakan kesepuluh sekawan itu ternyata hanya diteriakkan di mulut demi menguat-nguatkan nyali karena sesungguhnya mereka itu orang-orang yang penakut. Kenyataanya, kecuali Debut Awaludin, tak ada yang berani melawan keberingasan para pembuli itu. Sejak kecil sepuluh sekawan itu adalah kawanan yang lemah, bodoh, dan selalu bertengkar dan saling tuduh. Hingga dewasa, sekarang mereka tetap begitu."

(Hirata, 2019: 35)

Kutipan di atas menunjukkan bahwa tokoh kesepuluh sekawan tersebut memang pada dasarnya adalah orang-orang biasa yang terkumpul berdasarkan kesamaan nasib dan status sosial yang mereka miliki. Mereka kerap kali mengalami diskriminasi sosial dikarenakan status sosial yang mereka miliki. Orang-orang yang lahir dari kalangan kurang berada akan selalu cenderung mengalami penindasan dan penganiayaan secara sosial.

(2) Permasalahan Status Sosial

Permasalahan mengenai status sosial dalam novel ditunjukkan oleh sikap tokoh kesepuluh sekawan yang kerap mengalami perbedaan tempat dikarenakan faktor ekonomi dan akademik yang kurang memadai. Status sosial masih menjadi salah satu hal yang diperbandingkan dalam lingkungan masyarakat. Siapa yang berjaya akan dipuji dan dihargai namun sebaliknya jika tidak berjaya maka tidak akan dipuji dan tidak dihargai. Perbedaan status sosial yang dimiliki oleh seseorang dapat mengubah hal-hal yang tabu menjadi tidak tabu bahkan berani untuk melakukan tindakan yang dilarang dalam hukum negara, seperti: melakukan aksi penyogokan atau penyuapan. Hal ini dapat terlihat dari kutipan berikut. 
“Aku sudah tau itu dari dulu, Nah! Kita belum merdeka dalam pendidikan! Kita sekolah masih macam orang terjajah!.”

(Hirata, 2019: 78)

"Kau kerja sampai presiden berganti-ganti lima belas kali, gaji pelayan warung kopi takkan cukup untuk kuliah kedokteraan, Nong!'

(Hirata, 2019: 105)

Bentuk perbedaan status sosial, yang paling sering terjadi dalam lingkungan masyarakatsaat ini adalah tindakan korupsi, dimana kebanyakan orang-orang yang melakukan tindakan korupsi ialah orang-orang yang berasal dari kalangan status sosial yang tinggi. Hal ini terlihat dalam kutipan berikut.

"Seiring meriahnya orang nyolong duit rakyat sehingga korupsi menjadi endemik, demand pencucian uang melejit, jauh melampaui supply. Teknik korupsi makin lihai, makin sistematis, makin sukses, makin rakus, duit korupsi melimpah ruah. Duit haram itu tak bisa begitu saja dimasukkan ke bank, dijadikan bisnis, atau dibelanjakan karena bisa diendus oleh yang berwajib. Satu-satunya cara, dicuci dulu baru kemudian berpesta pora."

(Hirata, 2019: 53)

Kutipan di atas menunjukan bahwa hingga saat ini masih sering ditemukan kasus mengenai permasalahan status sosial. Permasalahan seperti ini masih menjadi pelik di negeri ini.

(3) Permasalahan Pendidikan

Permasalahan pendidikan dalam novel ditunjukkan oleh tokoh kesepuluh sekawan yang selama masa SMA sering kali mengalami permasalahan pendidikan dikarenakan tidak memiliki biaya dan kurangnya kemampuan akademik. Hal ini dapat dilihat dari kutipan berikut.

"Hitungan mencongklak begini saja kau tak becus, Mardinah! Berdiri di sudut!" bentak Ibu Desi Mal. Dinah berdiri lalu melangkah dengan gemetar ke sudut kelas...."

(Hirata, 2019: 9)

"Waktu sekolah dulu, bercita-cita saja kita tak berani, kita selalu dihina karena bodoh. Kini anak kawan kita diterima di Fakultas Kedokteraan. Aku mendukung! Aku siap merampok!"

(Hirata, 2019: 85)

Kutipan di atas mengambarkan bahwa semasa SMA kesepuluh sekawan tersebut selalu mengalami permasalahan pendidikan, mereka yang merupakan anak-anak dari masyarakat kalangan status menengah ke bawah kerap kali tidak dianggap, dicampakkan, dan diasingkan kebangku paling belakang dan disebut sebagai penghuni bangku belakang.

Permasalahan pendidikan dalam novel juga ditunjukkan oleh tokoh Aini anak Dinah. Aini merupakan anak sulung dari Dinah, yang pada awalnya memiliki sikap pemalas, tidak pintar, dan tidak memiliki cita-cita, akhirnya memiliki cita-cita sebagai seorang dokter, ia pun mulai giat belajar setelah kematian sang ayah karena sakit. Akhirnya setelah berusaha belajar dengan giat, Aini pun diterima sebagai mahasiswa Fakultas Kedokteraan Universitas Negeri. Sayangnya cita-cita Aini harus tertunda dikarenakan ibunya Dinah tidak memiliki biaya untuk menyekolahkannya. Hal ini dapat dilihat dari kutipan berikut. 
“Tangkap! Tangkaplah orang miskin yang berjuang agar anaknya bisa sekolah! Kita ini bukan merampok, Dinah! kita ini melawan ketidakadilan! Tengoklah banyaknya anak-anak pintar miskin yang tak dipedulikan Pemerintah! Tengoklah jurusan tertentu hanya dapat dimasuki orang-orang kaya! Tengoklah langkahnya anak-anak orang miskin jadi dokter! Mendaftar ke fakultas itu saja mereka tak berani! Padahal, kecerdasaan mereka siap diadu! Ilmu hendaklah hanya tunduk pada kecerdasaan, bukan pada kekayaan! Para pemimpin, birokrat, politisi, sibuk dengan periuk belanga mereka sendiri! Tanpa merampok bank itu, sampai kiamat kau takkan bisa menyekolahkan anakmu di Fakultas Kedokteraan!"

(Hirata, 2019: 117-118)

Kutipan di atas menunjukkan bahwa Aini harus mengubur cita-citanya untuk menjadi seorang dokter dikarenakan tidak ada biaya dan berasal dari keluarga miskin. Namun ditengah keputusaan Aini akan nasib kuliahnya, kesepuluh sekawan tersebut malah berencana untuk melakukan aksi perampokan bank demi mencari biaya kuliah agar Aini dapat melanjutkan pendidikan di perguruan tinggi. Mereka sampai rela untuk melakukan perbuatan yang melanggar hukum yakni merampok bank untuk mendapatkan uang $18 \mathrm{M}$ dan singkat cerita mereka pun akhirnya berhasil merampok bank dan mendapatkan uang tersebut.

Permasalahan kemiskinan, status sosial, dan pendidikan yang dialami oleh kesepuluh tokoh sekawan dan Aini membuktikan bahwa ketiga permasalahan tersebut memiliki keterikatan. Dimana tokoh kesepuluh sekawan melakukan aksi perampokan dikarenakan terdesak oleh kedaan sehingga melupakan bahwa perbuatan yang mereka lakukan adalah perbuatan yang melanggar hukum dan di satu sisi Trio Bastradin dan Duo Boron melakukan aksi pencucian uang dengan sengaja untuk menambah kekayaan mereka.

2. Fakta Sosial

Fakta sosial yang di temukan di dalam novel di lihat dari gambaran permasalahan yang terdapat di dalam novel, sebagai berikut:

(1) Ketidakadilan

Ketidakadilan di dalam novel ini tunjukkan oleh permasalahan sosial yang di alami oleh tokoh Aini dalam memperjuangkan pendidikan. hal ini sesuai degan kenyataan sosial yang terjadi di dalam masyarakat saat ini bahwa terdapat hukum kausualitas, di mana siapa yang berjaya dia akan berkuasa dan sebaliknya. Bahkan ada beberapa istilah yang sering di dengar di kalangan masyarakat bahwa "Pendidikan hanya untuk orang-orang yang berada" istilah seperti ini merujuk pada bentuk ketidakadilan dalam pemerolehan pendidikan bagi masyarakat. Hal ini secara nyata dapat dilihat pada beberapa kasus anak putus sekolah di karenakan terkendala oleh biaya pendidikan yang cukup tinggi. Contoh kasus mengenai permasalahan pendidikan adalah yang cukup menarik perhatian media adalah kasus mengenai anak putus sekolah di daerah Pekan Baru, Riau. Data yang tercatat dari harian Antarnews.com pada tanggal 1 Januari 2020 mencatat bahwa terdapat 94 ribu anak putus sekolah dikarenakan biaya hal ini dapat dilihat dari kutipan artikel berikut

"Sementara persentase anak usia 7-17 tahun yang mengalami putus sekolah mencapai 44,37 persen, hal ini menempatkan provinsi ini berada di ururtan ketiga di bawah Jambi dan Banten yang masing-masing sebesar 46,36 persen dan 49,63 persen." 
Kutipan artikel di atas menunjukkan bahwa pendidikan masih menjadi salah satu faktor permasalahan terbesar di Indonesia hampir setiap tahun jumlah anak putus sekolah di Indonesia masih tergolong tinggi. Hal ini menunjukkan bahwa bentuk keadilan dalam ranah pendidikan masih harus menjadi perhatian khusus bagi pemerintah.

(2) Kepedulian

Bentuk kepedulian di dalam novel ini juga di tunjukkan oleh sikap ke sepuluh sekawan yang telah rela membantu dalam mencari dan melakukan apa saja demi untuk membantu mencari biaya kuliah Aini. Bahkan Hal ini dapat dilihat dari kutipan berikut.

"Kalau kita tertangkap, masa lalu tertangkap. Kalau seorang anak tidak sekolah, masa depan jadi musibah. Aku ikut!"

(Hirata, 2019: 85)

Kutipan di atas menunjukkan mereka rela membuat rencana untuk merampok bank demi untuk membantu mencari biaya kuliah, Aini anak Dinah. Dalam kehidupan masyrakat sehari-hari saat ini bentuk rasa peduli antar sesama manusia ini sudah mulai memudar, namun dalam beberapa kasus masih ditemukan beberapa orang yang masih mau peduli akan sesama manusia seperti pda salah satu kisah inspiratif Dion Wiyoko yang peduli akan nasib pendidikan melalui fotografi. Dikutip dari Kompas.com (8 Oktober 2020) Dion yang merupakan seorang forografer mengungkapan mengenai rasa pedulinya terhadap permasalahan pendidikan yang saat ini. Hal ini terlihat dari salah satu kutipan berikut.

"Melalui hobi fotografi saya bisa memberikan kontribusi untuk meng-capture anak-anak atau adik-adik yang kurang beruntung dalam masalah fasilitas belajar online."

Kutipan di atas menunjukkan bahwa rasa peduli antarDiskrimi sesama manusia adalah hal positif yang patut untuk di contoh, karena rasa peduli adalah salah satu cerminan karakter yang baik dalam masyarakat

(3) Diskriminasi Sosial

Tindakan diskriminasi yang terdapat dalam novel ini ditunjukkan oleh tokoh Trio Bastradin dan Duo Boron yang kerap kali melakukan tindakan pembully-an terhadap kesepuluh sekawan. Hal ini dapat dilihat dari kutipan berikut. "Kian hari Bastardin kian brutal pada Salud karena percaya pada anggapan mistik segelintir orang udik bahwa semakin macam setan wajah seseorang semakin setan macam tabiatnya. Bahwa, orang semcam itu terkutuk, pembawa sial untuk kampung sehingga harus dimusuhi, bahkan diusir."

(Hirata, 2019: 20)

Hal tersebut menunjukkan bahwa Trio Bastardin dan Duo Boron adalah anak-anak pembully yang suka menindas kaum yang lemah dalam hal ini yakni kesepuluh sekawan dikarenakan perbedaan status sosial.

Kasus seperti ini kerap terjadi di dalam kehidupan nyata kasus-kasus seperti ini terjadi karena beberapa faktor salah satunya karena faktor psikologis, di mana pada faktor psikologis ini yang paling berperan adalah emosi dari orang yang melakukan tindakan pembullyan yakni berupa penyaluran hasrat yang tidak tersalurkan dengan baik sehingga mereka melakukan tindakan diskriminasi sosial berupa tindakan pembullyan guna memuaskan hasrat yang tidak tersalurkan. Dan dalam beberapa kasus tindakan pembullyan dapat menyebabkan trauma mental yang mendalam bagi para korban. 
Bentuk kasus pembullyan yang cukup parah dan terjadi beberapa waktu lalu, yakni kasus seorang siswi SD 2 Wirosari Ngadiman yang mengalami depresi berat karena di bully oleh teman-teman kelasnya. Dilansir dari harian regional.kompas.com (8 Februari 2020) RS adalah salah satu siswa di SDN 2 Wirosari yang sempat mengalami pembullyan hingga mengalami depresi berat, seperti yang dapat di lihat dari salah satu kutipan artikel di berikut.

"Jam dinding pecah dan kami belum bisa ganti karena kata pihak sekolah harganya Rp.300.000. Sejak saat itu anak saya selalu dibully, bahkan pernah disekap di kelas oleh teman-teman sekelas. Rambutnya dijambak, diludahi, disiram air, dan kekerasan lain. kami sudah konfirmasi ke sekolah, tetapi respons tidak baik, bahkan suami saya diusir." Kata Masrikah ibu RS.

Kutipan artikel di atas dapat di lihat bahwa kasus pembullyan masih menjadi permasalahan yang harus diperhatikan dalam lingkungan masyarakat dan pemerintah. Jika kasus-kasus seperti ini terus dibiarkan bukan tidak memungkinkan bahwa akan menganggu aspek kejiwaan dan psikologis para korban. Maka sangat diperlukan koordinasi dan kerjasama yang baik oleh orangtua dan lingkungan belajar anak serta pemerintah guna mengurangi tingkat kasus bullying di Indonesia.

(4) Kaidah Hukum

Bentuk penerapan kaidah hukum dalam novel Orang-Orang Biasa Ordinary People karya Andrea Hirata ini ditunjukkan oleh tokoh Inspektur Abdul Rojali ketika ia tidak mau menerima uang sepeserpun ketika ada sekelompok anggota yang ingin menyuapnya namun ia dengan tegas menolak tawaran tersebut. Hal ini dapat dilihat dari kutipan berikut.

"Inspektur membuka bungkusan kertas itu. Tebal duit pecahan tertinggi di dalamnya, baru, dan masih terikat label dari bank. Sepintas dia tahu belasan juta jumlah uang itu."

"Sepi di jembatan saat itu. Tak ada siapa-siapa. Tak ada orang yang melihatnya menerima uang itu dan ingat, dia tidak meminta uang pada siapa pun. Kedua alasan itu selalu lebih dari cukup untuk membuat seorang aparat mengkhianati sumpah jabatannya."

(Hirata, 2019: 124-125)

Kutipan di atas menggambarkan bahwa Inspektur Abdul Rojali adalah seorang aparat kepolisian yang sangat menjunjung tinggi sumpah jabatan dan mentaati semua hukum dan aturan undang-undang yang ada, dia dengan besar hati menolak semua hal yang berbau penyuapan, penyogokan, dan setia melaksanakan tugasnya sebagai seorang anggota aparat kepolisian. Kebanyakan aparat pemerintahan melakukan tindakan korupsi dan pencucian uang yang dilandaskan atas dasar pemenuhuan kebutuhan pribadi dan sikap egois yang semata-mata bertujuan untuk memperkaya diri. Bentuk kasus korupsi yang sering kita dengar seperti: kasus pencucian uang yang pernah dilakukan oleh salah satu ketua umum partai demokrat yakni Anas Urbaningrum yang pernah terjerat kasus korupsi dan pencucian uang (money politic) pada tahun 2016 yang lalu. Dikutip dari harian Acch.kpk.go.id (14 Januari 2016) menyatakan bahwa Anas melakukan beberapa tindakan korupsi sekaligus yang jika ditotalkan dana yang dia korupsikan sebanyak $71.5 \mathrm{M}$ dari berbagai proyek pemerintahan yang di pegang. Hal ini menunjukkan faktor psikologis sangat berperan terhadap seseorang dalam melakukan tindakan kejahatan, rasa egois dan ingin mengikuti hawa nafsu serta hasrat memperkaya diri sendiri menjadi faktor terbesar 
penyebab seseorang melakukan tindakan korupsi sehingga dia mampu untuk menghianati profesionalisme kerja yang dia pegang.

\section{PENUTUP}

\section{Kesimpulan}

Berdasarkan hasil penelitian yang telah dilakukan dapat disimpulkan bahwa terdapat hubungan kausualitas antara penggambaran permasalahan sosial dengan fakta sosial yang terdapat dalam novel Orang-Orang Biasa Ordinary People karya Andrea Hirata yakni bahwa novel ini mengemukakan mengenai penggambaran permasalahan sosial yang dialami oleh orang-orang biasa yang secara sosial kerap kali tidak menjadi perhatian dalam berbagai hal, mereka selalu kalah dikarenakan berasal dari kalangan masyarakat menengah ke bawah yang kerap kali tidak mendapatkan pendidikan yang layak, ekonomi yang kurang memadai, tidak memiliki status sosial yang tinggi, dan sebagian memiliki tingkat kemampuan akademik yang rendah. Permasalahan sosial yang digambarkan dalam novel meliputi permasalahan kemiskinan, permasalahan status sosial, dan permasalahan pendidikan yang relevan dnegn kenyataan dan menimbulkan sikap dan nilai sosial yang dapat dicerminkan dalam kehidupan sehari-hari di lingkungan bermasyarakat.

\section{Saran}

Berdasarkan dari hasil kesimpulan yang telah dipaparkan di atas. Selanjutnya akan dikemukakan mengenai beberapa saran yang terkait dengan penelitian ini, yakni: (1) Penelitian ini dapat dijadikan sebagai referensi untuk mempelajari lebih lanjut mengenai teori sosiologi sastra, dan dapat juga dimanfaatkan bagi mahasiswa dan masyarakat umum agar memperoleh suatu pengetahuan yang lebih mendalam tentang nilai-nilai sosial dalam sebuah karya sastra, (2)Diharapkan untuk penelitian selanjutnya, dapat meneliti mengenai nilai sosial ataupun realitas sosial dari perspektif sosiologi pengarang dan sosiologi pembaca pada novel Orang-Orang Biasa Ordinary People karya Andrea Hirata.

\section{DAFTAR PUSTAKA}

Habib. 2020. Cerita anak putus sekolah di kota Metro karena keterbatasan biaya. Diakses pada 14 Oktober 2020 pukul 10.15 wib dari https://www.cakra.tv/cerita-anak-putus-sekolah-di-kota-metro-karenaketerbatasan-biaya.html

Maruto,Riski. 2020. Gubernur:94 ribu anak di Riau putus sekolah karena keterbatasan biaya. Diakses pada 14 Oktober 2020 pukul 11.15 wib dari https://www.google.com/amp/s/m.antarnews.com/amp/berita/1230764/gub erur-94-ribu-anak-di-riau-putus-sekolah-karena-keterbatasan-biaya

Muhdi, Djuretna Imam. 1994. Moral dan Religi Menurut Emile Durkheim dan Henri Bergson. Yogyakarta: Kanisius.

Nugroho, Puthut Dwi Putranto, Hartik, Andi, dll. 2020. 4 kasus "Bullying" di sejumlah daera, dibanting, ke paving, amputasi, hingga korban depresi berat. Diakses pada 14 Oktober 2020 pukul 11;25 wib dari https://regional.kompas.com/read/2020/02/08/06060081/4-kasus-bullyingdi-sejumlah-daerah-dibanting-ke-paving-amputasi-hingga?page=all\#page2

Putri, Maria Adeline Tiara. 2020. Lewat fotografi, Dion Wiyoko tunjukkan kepedulian pada pendidikan. diakses pada 14 Oktober 2002 pukul 11.21 wib dari 
https://lifestyle.kompas.com/read/2020/10/08/165806920/lewat-fotografidion-wiyoko-tunjukkan-kepedulian-pada-pendidikan

Ritzer. Lht. George dan Goodman. Douglas J. 2004. Teori Sosiologi (Terjemahan). Yogyakarta: Kreasi Wacana.

Sari, Novita Linda. 2019. "Nilai-Nilai Sosial Dalam Novel Tentang Kamu Karya Tere Liye

Kajian Sosiologi Sastra “ Jurnal Ilmiah Korpus, Volume III, Nomor I, April 2019.

User. Super. 2016. Pencucian uang Anas Urbaningrum. Diakses pada 14 Oktober 2020 pukul 11.51 wib dari https://acch.kpk.go.id/id/artikel/fokus/pencucian-uang-anas-urbaningrum

Wellek, Rene dan Warren, Austin. 1995. Teori Kesusastraan (Terjemaban edisi ke-4). Jakarta: PT. Gramedia Pustaka Utama. 